\title{
Review
}

Chemotherapy

\section{Animal Hosts and Experimental Models of SARS-CoV-2 Infection}

\author{
Cristina Parolin $^{a}$ Sara Virtuoso $^{b}$ Marta Giovanetti $^{c}$ Silvia Angeletti ${ }^{d}$ \\ Massimo Ciccozzi ${ }^{\mathrm{e}}$ Alessandra Borsetti ${ }^{\mathrm{b}}$

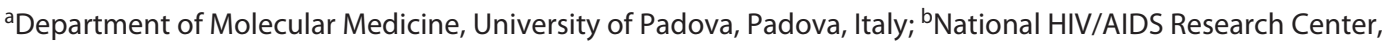 \\ Istituto Superiore di Sanità, Rome, Italy; 'Reference Laboratory of Flavivirus, Oswaldo Cruz Institute, Fundação \\ Oswaldo Cruz, Rio de Janeiro, Brazil; dUnit of Clinical Laboratory Science, University Campus Bio-Medico of Rome,

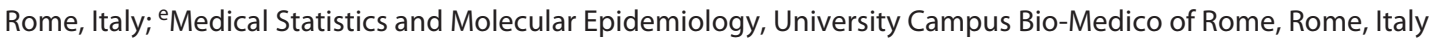

\section{Keywords}

Severe acute respiratory syndrome coronavirus $2 \cdot$ Animal hosts · Animal models · Cell models

\begin{abstract}
Viruses arise through cross-species transmission and can cause potentially fatal diseases in humans. This is the case of the severe acute respiratory syndrome coronavirus 2 (SARSCoV-2) which recently appeared in Wuhan, China, and rapidly spread worldwide, causing the outbreak of coronavirus disease 2019 (COVID-19) and posing a global health emergency. Sequence analysis and epidemiological investigations suggest that the most likely original source of SARSCoV-2 is a spillover from an animal reservoir, probably bats, that infected humans either directly or through intermediate animal hosts. The role of animals as reservoirs and natural hosts in SARS-CoV-2 has to be explored, and animal models for COVID-19 are needed as well to be evaluated for countermeasures against SARS-CoV-2 infection. Experimental cells, tissues, and animal models that are currently being used and developed in COVID-19 research will be presented.
\end{abstract}

(c) 2021 S. Karger AG, Basel

\section{Introduction}

A novel coronavirus, severe acute respiratory syndrome coronavirus 2 (SARS-CoV-2) emerged in Wuhan, Hubei Province, China, in December 2019 causing a syndrome termed by the World Health Organization (WHO) "COVID-19" on February 11, 2020 [1-4] and recognized as a pandemic on March 11, 2020 [5]. Coronaviruses are enveloped viruses with a positive sense single-stranded RNA genome (26-32 kb) [6], one of the largest known genomes among the RNA viruses [7]. Within the last 2 decades, 2 coronaviruses have been introduced into the human population, the SARS-CoV and the Middle East respiratory syndrome-CoV (MERS-CoV) and, by crossing the species barrier and causing severe disease spread from person to person. SARS-CoV emerged in China in 2002 from Chinese horseshoe bats and transmitted to human by human civet intermediate reservoirs and resolved within a year, causing 8,437 infected people with 813 deaths in 27 different countries worldwide, and resulting in a $9.6 \%$ fatality rate [8]. Bats may be the primary reservoir, and camels the intermediate host for MERS-CoV, originated in the Middle East and remaining largely restricted in the Arabian peninsula, resulting in 2,229 cases

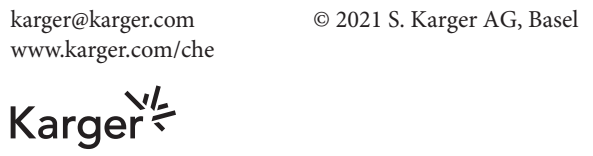

Alessandra Borsett

National HIV/AIDS Research Center

Istituto Superiore di Sanità

Viale Regina Elena 299, IT-00162 Rome (Italy)

alessandra.borsetti@iss.it 
and 858 deaths with a case mortality rate of 35\% [9]. Human coronaviruses (HCoVs), namely, HCoV-E299 (-CoV), HCoV-NL63 (-CoV), HCoV-OC43 (-CoV), and HCoV-HKU1 (-CoV), usually cause mild, both upper and lower respiratory tract infections in humans. $\mathrm{HCoVs}$ are thought to have emerged from an animal source, and then, other amplifier hosts might have played a role of becoming epidemiological animal reservoirs. Interestingly, evidence indicates $95 \%$ genetic homology of RNA sequence of $\mathrm{HCoV}-\mathrm{OC} 43$ to the one of the bovine $\mathrm{BCoV}$, speculating transmission from cattle, the zoonotic ancestor, to humans 100 years ago [10]. The identification of animal reservoirs plays a crucial role in effective disease control.

\section{Animal Reservoirs of SARS-CoV-2}

Most of viral diseases are caused by zoonotic pathogens maintained by wildlife reservoir hosts [11]. Bats are a natural reservoir host of different families of viruses, many of which cause severe human diseases [12, 13]. Viruses can spill over from the host to other animals and humans, causing disease outbreaks worldwide. The bat Rhinolophus (horseshoe bat) is speculated as the source of SARS-CoV-2 [2]; however, the possibility exists for additional interspecies transmissions, and the precise route of transmission of the virus into the human population has not been established yet. Phylogenetic analysis revealed SARS-CoV-2 as a newly emerged strain of $\beta$-coronavirus that shared 79.6 and $96.2 \%$ sequence identity with SARS-CoV-1 and bat Co-RaTG13, respectively, suggesting a zoonotic origin from the likely bat reservoir $[14,15]$. RaTG13 was detected in bat Rhinolophus affinis from Yunnan Province, far away from Hubei Province. Divergence dates between SARS-CoV-2 and RaTG13 were estimated between 40 and 70 years ago in horseshoe bats. Similar to what was observed with SARS and MERS, the possible involvement of an intermediate host as a plausible conduit for transmission to humans has been considered. Specifically, Guangdong Pangolin-CoV genome is very closely related to SARS-CoV-2, sharing $92.4 \%$ sequence similarity; thus, pangolin could be responsible for the zoonotic event $[16,17]$. SARS-CoV-2 could have been for decades in bats and been transmitted to other hosts such as pangolins. Unlike SARS-CoV, the spike (S) glycoprotein of SARS-CoV-2 harbors a unique furin cleavage site (PRRA) before the $\mathrm{S} 1 / \mathrm{S} 2$ region, which increases the transmissibility of this virus that is absent in bats and pangolins $[15,18]$. Although the exact origin of

Animal Host and Animal Models of the SARS-CoV-2 the PRRA motif from an animal virus has not yet been determined, this insertion is an independent natural event, probably due to a recombination, and fixed by the natural selection [18]. The currently available data do not clarify whether the origin of the virus is due to a natural selection in the wild animal reservoir before zoonotic transfer or natural selection in humans following zoonotic transfer.

\section{Animals Naturally Infected with SARS-CoV-2}

\section{Dogs and Feline}

Naturally infections with SARS-CoV-2 have been documented in various animal species. SARS-CoV-2 infection in dogs occurred in Hong Kong after close contact with people infected with the virus developing detectable antibodies against SARS-CoV-2 [19, 20]. In addition, genetic analysis revealed that dog and human viral sequences were closely related. Other human-to-dog transmissions have been reported in the Netherlands and in New York State confirmed by analysis of neutralizing antibodies against SARS-CoV-2 [21]. Conversely, neither France nor Spain tested positive dogs living with an individual infected with SARS-CoV-2 [22, 23]. Several human-tofeline transmissions have been documented [24-26]. In January 2020, in Wuhan, antibodies against SARS-CoV-2 were detected in domestic cats using ELISA and/or neutralization assay. Between March and June 2020, in Hong Kong, New York State in the USA, Belgium, and France, asymptomatic and/or symptomatic cats were tested positive for SARS-CoV-2 by RT-qPCR. Cats may infect other cats in close contact. In April 2020, in the Bronx Zoo in New York City, 1 tiger and 3 lions were found positive after interaction with SARS-CoV-2-infected zookeeper [27].

\section{Minks}

In April 2020, minks in 2 separate farms in the Netherlands developed signs of breathing and gastrointestinal disorders, with a mortality of $1.2-2.4 \%$ for a presumed human-to-mink transmission of SARS-CoV-2, workers at the farm having been previously tested positive for coronavirus disease 2019 (COVID-19). In November 2020, the Danish National Institute of Public Health announced the alert for back spillover of SARS-CoV-2 from mink farms into the community. During the passage through minks, the virus mutated in the $S$ protein-encoding gene. In the viral samples from minks and humans, researchers identified mutations that were then used to 
confirm that the people on the farm were infected by the viruses from the animals, and the mutations were suggestive of the virus adaptation to this new host $[28,29]$. It is unclear how SARS-CoV-2 has been introduced in the farms. A likely scenario for the infection of minks is human-to-animal transmission, although virus could potentially be introduced by wild mustelids or other wildlife, as shown by other virus infections like influenza viruses. Minks are Mustelidae-like ferrets that have been used as animal models of COVID-19 owing to their susceptibility to the virus and transmission between ferrets. The virus's rapid spread in mink makes this animal a potential nonhuman reservoir of viral source that can easily infect humans, and surveillance at the human-animal interface is highly recommended. Natural or experimental animal host susceptibility to SARS-CoV-2 is shown in Figure 1.

\section{Animal Models of COVID-19}

Animal models are important tools both for studying the pathogenesis of infectious diseases and for the preclinical evaluation of vaccines and antivirals against virus infections [30,31]. Several animal models have been used to study COVID-19 with varying susceptibility of the host to SARS-CoV-2 infection, suggesting a species-specific role for angiotensin-converting enzyme 2 (ACE2). The ACE2 is the host cell receptor responsible for mediating infection of SARS-CoV-2. The S glycoprotein mediates binding to ACE2, followed by proteolytic cleavage by protease serine 2 (TMPRSS2), which triggers fusion of viral and cellular membranes. In this regard, species-specific differences in the ability of ACE2 to bind the S protein for virus entry has been predicted in silico and demonstrated experimentally in vitro and correlated with susceptibility to SARS-CoV-2 infection of some species tested in experimental protocols [32-34]. In accord with this, mice are resistant to SARS-CoV-2 infection [35]. Animal models currently being used in COVID-19 research are shown in Table 1.

\section{Mouse}

Mice are widely used in infectious disease research, even though often, in order to be susceptible to the infection, they need to be genetically modified. Otherwise, the virus needs to be adapted for the growth in different species. SARS-CoV-2 uses cellular surface ACE2 protein as a primary receptor for cell attachment and entry, and mouse ACE2 does not bind efficiently to the viral S protein [33,

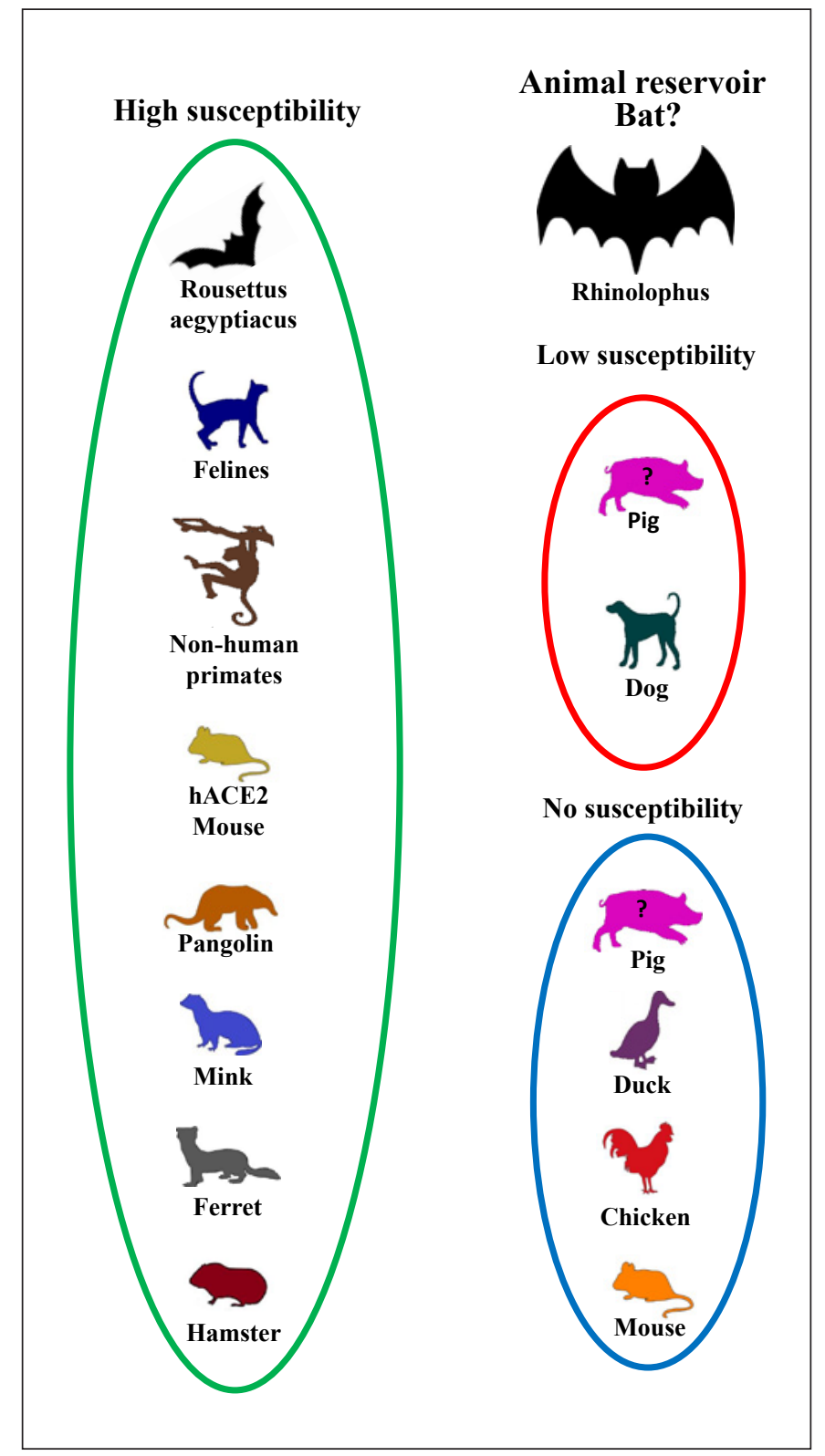

Fig. 1. Susceptibility of animal hosts to SARS-CoV-2 infection. High susceptibility: felines, NHPs, hACE2 mice, pangolins, ferrets, minks, hamsters; low susceptibility: dogs and pigs (in one experimental study [68]); no susceptibility: pigs (in one experimental study [52]) to SARS-CoV-2 infection. SARS-CoV-2, severe acute respiratory syndrome coronavirus 2; hACE2, human ACE2; NHP, nonhuman primate.

34]. The ways to overcome this problem are to adapt either the host or the virus. Mouse-adapted SARS-CoV-2 strain with binding affinity to mouse ACE2 has been obtained after sequential passaging of virus in mouse lung tissues [36]. Infection of young adult and aged $\mathrm{BALB} / \mathrm{c}$ mice with
10

Chemotherapy 2021;66:8-16 DOI: $10.1159 / 000515341$
Parolin/Virtuoso/Giovanetti/Angeletti/ Ciccozzi/Borsetti 
Table 1. Animal models of SARS-CoV-2

\begin{tabular}{|c|c|c|c|c|c|c|}
\hline $\begin{array}{l}\text { Animal } \\
\text { species }\end{array}$ & $\begin{array}{l}\text { Susceptibility } \\
\left({ }^{*} \text { natural } /{ }^{\circ} \text { experimental }\right. \\
\text { infection })\end{array}$ & $\begin{array}{l}\text { Clinical } \\
\text { signs }\end{array}$ & Immune response & Advantages & Disadvantages & Refs. \\
\hline Bat & ${ }^{*}$ High $/{ }^{\circ}$ high & No & Yes & Helpful for transmission & $\begin{array}{l}\text { Wildlife animal and not } \\
\text { easy to handle }\end{array}$ & {$[2,14,15]$} \\
\hline Mouse & *None/ ${ }^{\circ}$ high & Yes & Yes & $\begin{array}{l}\text { Useful for pathogenesis, immune } \\
\text { response, vaccines, and } \\
\text { therapeutics }\end{array}$ & $\begin{array}{l}\text { Transgenic mice, high } \\
\text { cost, and mild infection }\end{array}$ & {$[36-41]$} \\
\hline Hamster & ${ }^{*}$ None $/{ }^{\circ}$ high & Yes & Yes & $\begin{array}{l}\text { Useful for transmission, } \\
\text { pathogenesis, immune response, } \\
\text { and therapies }\end{array}$ & $\begin{array}{l}\text { Mild infection and no } \\
\text { severe disease }\end{array}$ & {$[46-50]$} \\
\hline Ferret & ${ }^{*}$ None $/{ }^{\circ}$ high & Yes & Yes & $\begin{array}{l}\text { Useful for transmission, } \\
\text { pathogenesis, and therapies }\end{array}$ & $\begin{array}{l}\text { Mild infection and no } \\
\text { severe disease }\end{array}$ & {$[51-54]$} \\
\hline Mink & ${ }^{*} \mathrm{High} /{ }^{\circ}$ not done & Yes & Yes & $\begin{array}{l}\text { Useful for transmission, } \\
\text { pathogenesis, and therapies }\end{array}$ & High cost & {$[29]$} \\
\hline Monkey & ${ }^{*}$ None $/{ }^{\circ}$ high & Yes & Yes & $\begin{array}{l}\text { Suitable for transmission, } \\
\text { pathogenesis, immune response, } \\
\text { vaccines, and therapies }\end{array}$ & $\begin{array}{l}\text { Transient clinical signs } \\
\text { and housing cost }\end{array}$ & $\begin{array}{l}{[43,45,53,55,56,} \\
58-65]\end{array}$ \\
\hline Dog & $*$ Low $/{ }^{\circ}$ low & No & Yes & Not useful & Not applicable & {$[54,67]$} \\
\hline Cat & ${ }^{*}$ High $/{ }^{\circ}$ high & Yes & Yes & Not useful & Not applicable & {$[66,67]$} \\
\hline Pig & $\begin{array}{l}{ }^{*} \text { None } /{ }^{\circ} \text { none or low in } \\
\text { one experimental study }\end{array}$ & No & $\begin{array}{l}\text { No/low in one } \\
\text { experimental study }\end{array}$ & Low useful & Not applicable & {$[52,67]$} \\
\hline Poultry & ${ }^{*}$ None $/{ }^{\circ}$ none & No & No & Not useful & Not applicable & {$[68,69]$} \\
\hline
\end{tabular}

SARS-CoV-2, severe acute respiratory syndrome coronavirus 2 .

adapted SARS-CoV-2 resulted in replication in both upper and lower airways, with severe symptoms in the aged mice. The disadvantage of mouse-adapted viruses may be in the clinical features of the infection that do not recapitulate all aspects of the human disease. Another approach has been to modify the receptor-binding domain in the virus $S$ protein to bind mouse ACE2 protein. The virus replicated in animals with a limited degree of clinical illness and mild disease symptoms, suggesting that even though ACE2 may be necessary for infection, it is not sufficient to determine the outcome of infection. Transgenic mice expressing human ACE2 (hACE2) receptor support SARS-CoV-2 infection. Different strategies have been adopted for expressing hACE2 in mice, including the use of the mouse ACE2 promoter or a heterologous gene promoter, as well as the transduction by means of adenovirus or adeno-associated virus expressing hACE2 as a transgene [31, 37-41]. Successfully studies showed mice that mimic human COVID-19 symptoms; thus, a variety of antivirals and vaccine candidates have been tested [4245]. Thus, mice are potentially good candidates for evaluating the efficacy of antiviral drugs.

Animal Host and Animal Models of the SARS-CoV-2

\section{Hamster}

Syrian hamsters intranasally inoculated are highly permissive to SARS-CoV-2 infection, with high levels of virus replication and histopathological evidence of disease that closely mimic those displayed by human COVID-19 patients. High levels of viral RNA were evident in the nasal mucosa, lower respiratory epithelial cells, and small intestine, which could be useful for the evaluation of therapeutic agents and vaccines. Analysis of neutralizing antibodies, detected as early as 7 days after infection, revealed protection against rechallenge with SARS-CoV-2, while naive hamsters were efficiently protected by passive immunization against high dose of SARS-CoV-2. Virus transmission to naive cohoused hamsters has been successful observed [46-48]. Recently, 2 different groups, by adopting the hamster model, have been able to show that the D614G variant in S protein results in increased virus infectivity in the upper airway of the animals and in enhanced transmissibility $[49,50]$. In addition, sera from variant-infected hamsters can efficiently neutralize the virus, suggesting that SARS-CoV-2 vaccines, all of which are based on the D614 variant, will protect against the 
G614 variant. These results confirm hamsters a useful animal model in virus transmission studies.

\section{Ferret}

Ferrets are of special relevance to laboratory studies of respiratory viruses since their respiratory tract is anatomically comparable to the human one. Ferrets are susceptible to experimental infection by SARS-CoV-2, via direct contact and via the air, and are capable of replicating and transmitting the virus to other noninfected animals. Shedding of SARS-CoV-2 is observed in nasal and oropharyngeal swabs. Infectious virus was detected in the upper respiratory and gastrointestinal tract, and viral RNA was found in the saliva, urine, rectal swabs, and feces. All ferrets possessed serum with anti-SARS-CoV-2 antibody, and high titers of neutralizing antibodies were detected at day 21 . Virus causes a milder respiratory syndrome in ferrets than in humans, with undetectable or mild clinical alterations. It should be noted the consistency of the results obtained from different studies [51-54]. Ferrets are a valuable model for better understanding transmission and pathogenesis of COVID-19.

\section{Nonhuman Primate Models}

The animal model of infectious diseases should reflect clinical course and pathology observed in humans to characterize viral pathogenesis and to evaluate antiviral agents and vaccines. For COVID-19, several animal species were investigated as models of human disease including the nonhuman primates (NHPs). NHPs are closely related to humans; they are invaluable models for studying emerging and re-emerging diseases. NHPs could be susceptible to SARS-CoV-2 infection, being symptoms of fever, diarrhea, and pneumonitis reported in rhesus macaques (Macaca mulatta), cynomolgus macaques (Macaca fascicularis), and African green monkeys (Chlorocebus aethiops). Replication of virus at high titers was observed in both the upper and lower respiratory tracts for 7-14 days $[55,56]$. Additionally, infected rhesus macaques developed humoral and cellular immune responses as well as robust protection against 28 days postinfection rechallenge, indicating full protection from reinfection [57]. In addition, as observed in older SARS-CoV-2-infected individuals, an adverse clinical outcome is associated with old rhesus macaque infected as compared to young rhesus macaque ones [53]. The use of different challenge stocks, dosages, and routes of infection in NHP models may contribute to a significant variation in the level and duration of viral replication observed in the control groups; therefore, comparative studies will need stan- dardized protocols and challenge virus stocks. NHP models have been useful for the testing of therapeutic agents as well as of several vaccine candidates [43, 45, 58-65].

\section{Dog and Cat}

One experimental infection study showed that dogs have a low susceptibility to SARS-CoV-2 [54, 67]. No clinical signs were detected. Some animals produced antibodies against the virus, and viral RNA was detected in rectal swabs while it was absent in organs of euthanized dogs. These data suggest that dogs are not promising animal models to study SARS-CoV-2.

Cats are susceptible to experimental infection $[66,67]$. Viral RNA was evident in the upper and low respiratory tracts and small intestines, and seroconversion was detected by using the ELISA test. Naive cats were shown to be susceptible to the infection if they were in close contact with infected cats shedding viral RNA in tissue and feces, representing a potential model for droplet transmission.

\section{Pig}

Domestic swine have the potential to significantly impact public health; thus, determination of the susceptibility of pigs to SARS-CoV-2 is critical. To this end, different research groups inoculated these animals intravenously, intranasally, ocularly, or orally with SARS-CoV-2. No clinical signs and no viral RNA in swabs or tissue samples have been detected, and there was no seroconversion. $\mathrm{Na}$ ive contact animals were also seronegative, indicating that pigs could not transmit the virus. These findings suggested that swine are not susceptible to SARS-CoV-2 infection [52]. A recent study contradicts the above reported one. Indeed, of the 16 animals experimentally inoculated, 2 of them seroconverted; virus was isolated from a pig, while another one displayed mild symptoms [67]. Viral RNA was detected in oral fluids and nasal wash from 2 animals. It should be taken into account that the considerable variation observed in this study may be due to the viral isolate, infectious dose, or breed of swine. Further investigations regarding the susceptibility of these species are needed.

\section{Poultry}

Experimental infection of chicken and ducks with SARS-CoV-2 has been described. Animals did not develop clinical signs, all swabs and organ samples were negative for SARS-CoV-2 RNA, and seroconversion was not observed. Cohoused naive animals were found to be seronegative, indicating no animal-to-animal transmission $[68,69]$. These finding suggested that poultry are not sus-
Parolin/Virtuoso/Giovanetti/Angeletti/ Ciccozzi/Borsetti 
Table 2. Cell line, primary cell, and organoid susceptibility to SARS-CoV-2

\begin{tabular}{|c|c|c|c|}
\hline Cell lines, primary cells, and organoids & Origins & Susceptibility & Refs. \\
\hline Vero E6 cell line (African green monkey) & Renal & High viral replication & {$[70,71]$} \\
\hline Caco-2 cell line (human) & Intestinal & Robust viral replication & {$[70,71]$} \\
\hline Calu-3 cell line (human) & Pulmonary & Robust viral replication & {$[70,71]$} \\
\hline HEK293T cell line (human) & Renal & Modest viral replication & {$[71]$} \\
\hline FRhK4 cell line (rhesus monkey) & Renal & High viral replication & {$[71]$} \\
\hline LLCMK2 cell line (rhesus monkey) & Renal & High viral replication & {$[71]$} \\
\hline Airway epithelial primary cells (human bronchi/bronchiolar) & Epithelial & Permissive to SARS-CoV-2 infection & {$[72-75]$} \\
\hline \multirow[t]{5}{*}{ Human organoids } & Bronchial & Permissive to SARS-CoV-2 infection; progeny virus & {$[78]$} \\
\hline & Pulmonary & Permissive to SARS-CoV-2 & {$[86]$} \\
\hline & Renal & Permissive to SARS-CoV-2 infection; progeny virus & {$[87]$} \\
\hline & Hepatic & Permissive to SARS-CoV-2 infection; progeny virus & {$[83]$} \\
\hline & Intestinal & Permissive to SARS-CoV-2 infection; progeny virus & {$[81,84,85]$} \\
\hline
\end{tabular}

SARS-CoV-2, severe acute respiratory syndrome coronavirus 2 .

ceptible to the virus, and therefore, they do not represent suitable animal models for studies of SARS-CoV-2 infection.

\section{Fruit Bat}

Rousettus aegyptiacus fruit bat is genetically divergent from the predicted host reservoir Rhinolophus horseshoe bat. Experimental studies revealed that $R$. aegyptiacus is susceptible to SARS-CoV-2. Intranasal inoculation resulted in viral replication in the upper respiratory tract, with shedding of live virus and bat-to-bat transmission. Viral RNA was detected at a lower level in other organs, including the heart, skin, and intestine. Bats developed weak antibody responses, and clinical signs were absent [52]. The capacity of fruit bats to carry and transmit the virus makes this species a reservoir host, and therefore, it represents a useful model.

\section{Cell-Based Approaches}

Cell models of SARS-CoV-2 are essential for understanding the viral life cycle, tropism, and pathogenesis. Immortalized cell lines are widely utilized for virus isola- tion and for screening inhibitors against SARS-CoV-2. The simian kidney epithelial derived Vero E6 cell lines, expressing ACE2 and low levels of TMPRSS2, are highly susceptible and permissive to virus replication, and they are commonly used for virus isolation [70]. The human cell lines, among which renal HEK293T, intestinal Caco2, pulmonary Calu-3, and hepatic Huh-7, produce low titers of infectious virus and have been utilized in SARSCoV-2 infection experiments [70, 71]. Nonhuman cell lines, such as feline kidney CRFK and rhesus macaque kidney FRhK4 and LLCMK2, are adopted to SARS$\mathrm{CoV}-2$ replication studies [71]. The limitation of immortalized cell lines is that they do not accurately mimic human physiological conditions, and resulting biological observations need to be validated in primary human cells or in animal models. Primary human airway epithelial cells have been found to display cytopathic effects $96 \mathrm{~h}$ after SARS-CoV-2 infection [72-74]. Other primary human cells, nasal epithelial, large and lower airway epithelial, type I and type II pneumocytes (AT1 and AT2), ciliated and secretory airway epithelial (HAE), and gut enterocytes, are permissive to SARS-CoV-2 infection [75-77]. Recently, an important finding has been obtained in human lung epithelial cells and in primary hu- 
man airway tissue where increased infectivity of the $\mathrm{S}$ D614G variant of SARS-CoV-2 has been demonstrated [49]. These data suggest that the D614G mutation gives rise to enhanced virus transmissibility. In addition, serum samples from D614 virus-infected hamsters can efficiently neutralize the G614 virus from infecting cells, indicating that SARS-CoV-2 vaccines, which are all based on the D614 variant of the S protein, will protect against G614 virus variants.

Organoids are self-organized 3-dimensional assemblies of cells, generated by the primary tissue or pluripotent stem cells that exhibit physiological features of an organ. Organoids derived from human cells are particularly helpful for preclinical studies, by obviating the need to extrapolate results from one species to another. Organoids are also of interest for recapitulating the physiological effects of SARS-CoV-2, for investigating virus tropism and pathogenesis and for screening SARS-CoV-2 inhibitors. SARS-CoV-2 affects several organs causing severe damage of the lung; cardiovascular, intestinal, and neurological, and endothelial systems; kidney; and liver, showing direct effects on these tissues. Recent studies showed that human bronchial, lung, kidney, liver, intestinal, and vascular organoids are all permissive to SARSCoV-2 and may represent viral reservoir [78-84]. Antiviral effects of COVID-19 candidate therapeutic compounds have been evaluated in organoid systems [85-88]. Vascular and kidney organoids have been used to identify clinical-grade soluble ACE2 as an inhibitor of SARSCoV-2 infection [87, 88]. Liver ductal organoids support SARS-CoV-2 replication and virus infection impaired the bile acid transporting functions of cholangiocytes, resulting in the bile acid accumulation and consequent liver damage in patients [83]. A limitation of organoid models may be the lack of relevant immune cells - e.g., macrophages, that modulate severe disease. Cell lines and organoids and currently being used in COVID-19 research are summarized in Table 2.

\section{Conclusion}

In order to answer important questions on COVID-19 including pathogenesis, transmissibility, and immune response to SARS-CoV-2, as well as comorbidities and viral coinfections, in vivo investigations adopting the best animal models are needed for validation and translation in human studies. Animal models may also serve to evaluate therapeutic countermeasures and vaccines. Current literature data indicate that although most of the animal models could mimic many features of human COVID-19, however, none of them is capable of replicating the clinical outcomes related to high mortality and morbidity of the human disease. Furthermore, it has to be considered that the innate immune response, including the defense system against viruses, diverged during evolution among the animals, which may explain the differences in the rate of infection. Additional studies will be required to refine animal models of chronic diseases to gain further insights into molecular immune pathogenesis, diagnosis and treatment of COVID-19. NHPs are closer to humans and are the most relevant animal models to test interventions before deployment to human treatment. On the other side, ferrets, mice, and hamsters developed clinical signs of the infection that are very similar to the one developed in humans. These animals might be useful in answering many questions regarding the mechanism of action of antivirals, and safety and efficacy of vaccines. Animal and in vitro/ex vivo models can be adopted and pathogenesis and interventions assessed. Finally, wild animals such as bats and/or pangolins or a yet-to-be-identified animal host could serve as reservoirs of the SARS-CoV-2 or route of transmission to humans, and surveillance should be extensively done.

\section{Conflict of Interest Statement}

The authors have no conflicts of interest to declare.

\section{Funding Sources}

This research received no external funding.

\section{Author Contributions}

All authors contributed to the writing of this manuscript.

References

$$
\begin{aligned}
& 1 \text { Zhu N, Zhang D, Wang W, Li X, Yang B, Song } \\
& \text { J, et al. A novel coronavirus from patients with } \\
& \text { pneumonia in China, 2019. N Engl J Med. } 2020 \\
& \text { Feb;382(8):727-33. } \\
& 2 \text { Zhou P, Yang XL, Wang XG, Hu B, Zhang L, } \\
& \text { Zhang W, et al. A pneumonia outbreak associ- } \\
& \text { ated with a new coronavirus of probable bat } \\
& \text { origin. Nature. } 2020 \text { Mar;579(7798):270-3. } \\
& 3 \text { Gralinski LE, Menachery VD. Return of the } \\
& \text { Coronavirus: 2019-nCoV. Viruses. 2020 Jan; } \\
& \text { 12(2):135. } \\
& 4 \text { Salata C, Calistri A, Parolin C, Palù G. Corona- } \\
& \text { viruses: a paradigm of new emerging zoonotic } \\
& \text { diseases. Pathog Dis. 2019 Dec;77(9):ftaa006. } \\
& 5 \text { Cucinotta D, Vanelli M. WHO declares CO- } \\
& \text { VID-19 a pandemic. Acta Biomed. 2020 Mar; } \\
& \text { 91(1):157-60. }
\end{aligned}
$$

Parolin/Virtuoso/Giovanetti/Angeletti/ Ciccozzi/Borsetti 
6 Su S, Wong G, Shi W, Liu J, Lai AC, Zhou J, et al. Epidemiology, genetic recombination, and pathogenesis of Coronaviruses. Trends Microbiol. 2016 Jun;24(6):490-502.

7 Fehr AR, Perlman S. Coronaviruses: an overview of their replication and pathogenesis. Methods Mol Biol. 2015;1282:1-23.

8 World Health Organization. Cumulative Number of Reported Probable Cases of SARS [updated 2003 Jul 11]. Available from: http:// www.who.int/entity/csr/sars/country/2003_07_11/en/index.html.

9 World Health Organization. Global Alert and Response: Middle East Respiratory Syndrome coronavirus (MERS-CoV). 2014 [update 2014 May 7]. Available from: https://www.who.int/ csr/don/2014_05_07_mers_jordan/en/.

10 Vijgen L, Keyaerts E, Moës E, Thoelen I, Wollants E, Lemey P, et al. Complete genomic sequence of human coronavirus OC43: molecular clock analysis suggests a relatively recent zoonotic coronavirus transmission event. J Virol. 2005 Feb;79(3):1595-604.

11 Wang LF, Crameri G. Emerging zoonotic viral diseases. Rev Sci Tech. 2014 Aug;33(2):569-81.

12 Hayman DT. Bats as viral reservoirs. Annu Rev Virol. 2016 Sep;3(1):77-99.

13 Li W, Shi Z, Yu M, Ren W, Smith C, Epstein $\mathrm{JH}$, et al. Bats are natural reservoirs of SARSlike coronaviruses. Science. 2005 Oct; 310(5748):676-9.

14 Paraskevis D, Kostaki EG, Magiorkinis G, Panayiotakopoulos G, Sourvinos G, Tsiodras S. Full-genome evolutionary analysis of the novel corona virus (2019-nCoV) rejects the hypothesis of emergence as a result of a recent recombination event. Infect Genet Evol. 2020 Apr;79: 104212.

15 Zhou H, Chen X, Hu T, Li J, Song H, Liu Y, et al. A novel bat coronavirus closely related to SARS-CoV-2 contains natural insertions at the S1/S2 cleavage site of the spike protein. Curr Biol. 2020 Jun;30(11):2196-e3.

16 Lam TT, Jia N, Zhang YW, Shum MH, Jiang JF, Zhu HC, et al. Identifying SARS-CoV-2-related coronaviruses in Malayan pangolins. $\mathrm{Na}-$ ture. 2020 Jul;583(7815):282-5.

17 Xiao K, Zhai J, Feng Y, Zhou N, Zhang X, Zou $\mathrm{JJ}$, et al. Isolation of SARS-CoV-2-related coronavirus from Malayan pangolins. Nature. 2020 Jul;583(7815):286-9.

18 Barh D, Silva Andrade B, Tiwari S, Giovanetti M, Góes-Neto A, Alcantara LCJ, et al. Natural selection versus creation: a review on the origin of SARS-COV-2. Infez Med. 2020 Sep;28(3): 302-11.

19 OIE. COVID-19 (SARS-COV-2), Hong Kong (SAR-PRC). Available from: https://www.oie. int/wahis_2/public/wahid.php/Reviewreport/ Review?page_refer=MapFullEventReport\& reportid=33832.

20 Sit THC, Brackman CJ, Ip SM, Tam KWS, Law PYT, To EMW, et al. Infection of dogs with SARS-CoV-2. Nature. 2020 Oct;586(7831): 776-8.

21 AVMA (American Veterinary Medical Association). SARS-CoV-2 in Animals. 2020.
Available from https://www.avma.org/resources-tools/animal-health-and-welfare/covid-19/sars-cov-2-animals-including-pets.

22 Ruiz-Arrondo I, Portillo A, Palomar AM, Santibáñez S, Santibáñez P, Cervera C, et al. Detection of SARS-CoV-2 in pets living with COVID-19 owners diagnosed during the COVID-19 lockdown in Spain: a case of an asymptomatic cat with SARS-CoV-2 in Europe. Transbound Emerg Dis. 2020 Aug. Epub ahead of print.

23 Temmam S, Barbarino A, Maso D, Behillil S, Enouf V, Huon C, et al. Absence of SARS$\mathrm{CoV}-2$ infection in cats and dogs in close contact with a cluster of COVID-19 patients in a veterinary campus. One Health. 2020 Dec;10: 100164.

24 CDC. Confirmation of COVID-19 in Two Pet Cats in New York. Available from: https:// www.cdc.gov/media/releases/2020/s0422-covid-19-cats-NYC.html.

25 Sailleau C, Dumarest M, Vanhomwegen J, Delaplace M, Caro V, Kwasiborski A, et al. First detection and genome sequencing of SARS-CoV-2 in an infected cat in France. Transbound Emerg Dis. 2020 Nov;67(6): 2324-8.

26 OIE. A Case of a Belgian Cat Positive for Covid-19. Available from: https://www.oie.int/ fileadmin/Home/eng/Our_scientific_expertise/docs/pdf/COV 19/Belgium_28.03.20.pdf.

27 McAloose D, Laverack M, Wang L, Killian ML, Caserta LC, Yuan F, et al. From people to panthera: natural SARS-CoV-2 infection in tigers and lions at the Bronx Zoo. mBio. 2020 Oct 13; 11(5): $02220-20$.

28 Oreshkova N, Molenaar RJ, Vreman S, Harders F, Oude Munnink BB, Hakze-van der Honing RW, et al. SARS-CoV-2 infection in farmed minks, the Netherlands, April and May 2020. Euro Surveill. 2020 Jun;25(23):2001005.

29 Koopmans M. SARS-CoV-2 and the humananimal interface: outbreaks on mink farms. Lancet Infect Dis. 2020 Nov 20;S14733099(20):30912-9.

30 Sutton TC, Subbarao K. Development of animal models against emerging coronaviruses: from SARS to MERS coronavirus. Virology. 2015 May;479-480:247-58.

31 Pandey K, Acharya A, Mohan M, Ng CL, Reid SP, Byrareddy SN. Animal models for SARSCoV-2 research: a comprehensive literature review. Transbound Emerg Dis. 2020 Oct 31. Epub ahead of print.

32 Luan J, Lu Y, Jin X, Zhang L. Spike protein recognition of mammalian ACE2 predicts the host range and an optimized ACE2 for SARSCoV-2 infection. Biochem Biophys Res Commun. 2020 May;526(1):165-9.

33 Wan Y, Shang J, Graham R, Baric RS, Li F. Receptor recognition by the novel coronavirus from Wuhan: an analysis based on decadelong structural studies of SARS coronavirus. J Virol. 2020;94:e00127-20.

34 Zhao X, Chen D, Szabla R, Zheng M, Li G, Du $\mathrm{P}$, et al. Broad and differential animal angiotensin-converting enzyme 2 receptor usage by
SARS-CoV-2. J Virol. 2020 Aug;94(18): e00940-20.

35 Bao L, Deng W, Huang B, Gao H, Liu J, Ren L, et al. The pathogenicity of SARS-CoV-2 in hACE2 transgenic mice. Nature. 2020 Jul; 583(7818):830-3.

36 Gu H, Chen Q, Yang G, He L, Fan H, Deng YQ, et al. Adaptation of SARS-CoV-2 in BALB/c mice for testing vaccine efficacy. Science. 2020 Sep;369(6511):1603-7.

37 Jiang RD, Liu MQ, Chen Y, Shan C, Zhou YW, Shen XR, et al. Pathogenesis of SARS-CoV-2 in transgenic mice expressing human angiotensin-converting enzyme 2. Cell. 2020 Jul 9; 182(1):50-8.e8.

38 Leist SR, Dinnon KH 3rd, Schäfer A, Tse LV, Okuda K, Hou YJ, et al. A mouse-adapted SARS-CoV-2 induces acute lung injury and mortality in standard laboratory mice. Cell. 2020 Nov;183(4):1070-85.e12.

39 Dinnon KH 3rd, Leist SR, Schäfer A, Edwards CE, Martinez DR, Montgomery SA, et al. A mouse-adapted model of SARS-CoV-2 to test COVID-19 countermeasures. Nature. 2020 Oct;586(7830):560-6.

40 Bao L, Deng W, Huang B, Gao H, Liu J, Ren L, et al. The pathogenicity of SARS-CoV-2 in hACE2 transgenic mice. Nature. 2020 Jul; 583(7818):830-3.

41 Bao L, Gao H, Deng W, Lv Q, Yu H, Liu M, et al. Transmission of severe acute respiratory syndrome coronavirus 2 via close contact and respiratory droplets among human angiotensin-converting enzyme 2 mice. J Infect Dis. 2020 Jul;222(4):551-5.

42 Israelow B, Song E, Mao T, Lu P, Meir A, Liu F, et al. Mouse model of SARS-CoV-2 reveals inflammatory role of type I interferon signaling. J Exp Med. 2020 Dec;217(12):e20201241.

43 Gao Q, Bao L, Mao H, Wang L, Xu K, Yang M, et al. Development of an inactivated vaccine candidate for SARS-CoV-2. Science. $2020 \mathrm{Jul}$; 369(6499):77-81.

44 Smith TRF, Patel A, Ramos S, Elwood D, Zhu $\mathrm{X}$, Yan J, et al. Immunogenicity of a DNA vaccine candidate for COVID-19. Nat Commun. 2020 May;11(1):2601.

45 Yang J, Wang W, Chen Z, Lu S, Yang F, Bi Z, et al. A vaccine targeting the $R B D$ of the $S$ protein of SARS-CoV-2 induces protective immunity. Nature. 2020 Oct;586(7830):572-7.

46 Sia SF, Yan LM, Chin AWH, Fung K, Choy KT, Wong AYL, et al. Pathogenesis and transmission of SARS-CoV-2 in golden hamsters. Nature. 2020 Jul;583(7818):834-8.

47 Imai M, Iwatsuki-Horimoto K, Hatta M, Loeber S, Halfmann PJ, Nakajima N, et al. Syrian hamsters as a small animal model for SARSCoV-2 infection and countermeasure development. Proc Natl Acad Sci U S A. 2020 Jul; 117(28):16587-95.

48 Du S, Cao Y, Zhu Q, Yu P, Qi F, Wang G, et al. Structurally resolved SARS-CoV-2 antibody shows high efficacy in severely infected hamsters and provides a potent cocktail pairing strategy. Cell. 2020 Nov;183(4):1013-23. e13. 
49 Plante JA, Liu Y, Liu J, Xia H, Johnson BA, Lokugamage KG, et al. Spike mutation D614G alters SARS-CoV-2 fitness. Nature. 2020 Oct 26. Epub ahead of print.

50 Hou YJ, Chiba S, Halfmann P, Ehre C, Kuroda M, Dinnon KH 3rd, et al. SARS-CoV-2 D614G variant exhibits efficient replication ex vivo and transmission in vivo. Science. 2020 Dec; 370(6523):1464-8.

51 Kim YI, Kim SG, Kim SM, Kim EH, Park SJ, $\mathrm{Yu} \mathrm{KM}$, et al. Infection and rapid transmission of SARS-CoV-2 in Ferrets. Cell Host Microbe. 2020 May;27(5):704-e2.

52 Schlottau K, Rissmann M, Graaf A, Schön J, Sehl J, Wylezich C, et al. SARS-CoV-2 in fruit bats, ferrets, pigs, and chickens: an experimental transmission study. Lancet Microbe. 2020 Sep;1(5):e218-25.

53 Park SJ, Yu KM, Kim YI, Kim SM, Kim EH, Kim SG, et al. Antiviral efficacies of FDA-approved drugs against SARS-CoV-2 infection in ferrets. mBio. 2020 May;11(3):e01114-20.

54 Shi J, Wen Z, Zhong G, Yang H, Wang C, Huang B, et al. Susceptibility of ferrets, cats, dogs, and other domesticated animals to SARS-coronavirus 2. Science. 2020 May; 368(6494):1016-20.

55 Munster VJ, Feldmann F, Williamson BN, van Doremalen N, Pérez-Pérez L, Schulz J, et al. Respiratory disease in rhesus macaques inoculated with SARS-CoV-2. Nature. 2020 Sep; 585(7824):268-72.

56 Rockx B, Kuiken T, Herfst S, Bestebroer T, Lamers MM, Oude Munnink BB, et al. Comparative pathogenesis of COVID-19, MERS, and SARS in a nonhuman primate model. Science. 2020 May;368(6494):1012-5.

57 Deng W, Bao L, Liu J, Xiao C, Liu J, Xue J, et al. Primary exposure to SARS-CoV-2 protects against reinfection in rhesus macaques. Science. 2020 Aug;369(6505):818-23.

$58 \mathrm{Yu}$ J, Tostanoski LH, Peter L, Mercado NB, McMahan K, Mahrokhian SH, et al. DNA vaccine protection against SARS-CoV-2 in rhesus macaques. Science. 2020 Aug;369(6505):806-11.

59 Mercado NB, Zahn R, Wegmann F, Loos C, Chandrashekar A. Yu J. et al. Single-shot Ad26 vaccine protects against SARS-CoV-2 in rhesus macaques. Nature. 2020 Oct;586(7830): $583-8$.

60 van Doremalen N, Lambe T, Spencer A, BelijRammerstorfer S, Purushotham JN, Port JR, et al. ChAdOx1 nCoV-19 vaccine prevents SARS-CoV-2 pneumonia in rhesus macaques. Nature. 2020 Oct;586(7830):578-82.

61 Corbett KS, Edwards DK, Leist SR, Abiona OM, Boyoglu-Barnum S, Gillespie RA, et al. SARS-CoV-2 mRNA vaccine design enabled by prototype pathogen preparedness. Nature. 2020 Oct;586(7830):567-71.

62 Corbett KS, Flynn B, Foulds KE, Francica JR, Boyoglu-Barnum S, Werner AP, et al. Evaluation of the mRNA-1273 vaccine against SARSCoV-2 in nonhuman primates. N Engl J Med. 2020 Oct;383(16):1544-55.

63 Williamson BN, Feldmann F, Schwarz B, Meade-White K, Porter DP, Schulz J, et al.
Clinical benefit of remdesivir in rhesus macaques infected with SARS-CoV-2. Nature. 2020 Sep;585(7824):273-6.

64 Wang H, Zhang Y, Huang B, Deng W, Quan $\mathrm{Y}$, Wang W, et al. Development of an inactivated vaccine candidate, BBIBP-CorV, with potent protection against SARS-CoV-2. Cell. 2020 Aug;182(3):713-21.e9.

65 Deng W, Bao L, Gao H, Xiang Z, Qu Y, Song $Z$, et al. Ocular conjunctival inoculation of SARS-CoV-2 can cause mild COVID-19 in rhesus macaques. Nat Commun. 2020 Sep; 11(1):4400.

66 Halfmann PJ, Hatta M, Chiba S, Maemura T, Fan S, Takeda M, et al. Transmission of SARSCoV-2 in domestic cats. N Engl J Med. 2020 Aug;383(6):592-4.

67 Bosco-Lauth AM, Hartwig AE, Porter SM, Gordy PW, Nehring M, Byas AD, et al. Experimental infection of domestic dogs and cats with SARS-CoV-2: pathogenesis, transmission, and response to reexposure in cats. Proc Natl Acad Sci U S A. 2020 Oct;117(42):26382-8.

68 Pickering BS, Smith G, Pinette MM, EmburyHyatt C, Moffat E, Marszal P, et al. Susceptibility of domestic swine to experimental infection with SARS-CoV-2. Emerg Infect Dis. 2021 Jan; 27(1):104-12.

69 Suarez DL, Pantin-Jackwood MJ, Swayne DE, Lee SA, DeBlois SM, Spackman E. Lack of susceptibility to SARS-CoV-2 and MERS-CoV in poultry. Emerg Infect Dis. 2020 Dec;26(12): 3074-6.

70 Hoffmann M, Kleine-Weber H, Schroeder S, Krüger N, Herrler T, Erichsen S, et al. SARSCoV-2 cell entry depends on ACE2 and TMPRSS2 and is blocked by a clinically proven protease inhibitor. Cell. 2020 Apr;181(2):27180.e8.

71 Chu H, Chan JF, Yuen TT, Shuai H, Yuan S, Wang Y, et al. Comparative tropism, replication kinetics, and cell damage profiling of SARS-CoV-2 and SARS-CoV with implications for clinical manifestations, transmissibility, and laboratory studies of COVID-19: an observational study. Lancet Microbe. 2020 May;1(1):e14-23.

$72 \mathrm{Xu} \mathrm{H}$, Zhong L, Deng J, Peng J, Dan H, Zeng $\mathrm{X}$, et al. High expression of ACE2 receptor of 2019-nCoV on the epithelial cells of oral mucosa. Int J Oral Sci. 2020 Feb;12(1):8.

73 Ziegler CGK, Allon SJ, Nyquist SK, Mbano IM, Miao VN, Tzouanas CN, et al. SARS-CoV-2 receptor ACE2 is an interferon-stimulated gene in human airway epithelial cells and is detected in specific cell subsets across tissues. Cell. 2020 May;181(5):1016-e19.

74 Zhu N, Wang W, Liu Z, Liang C, Wang W, Ye $\mathrm{F}$, et al. Morphogenesis and cytopathic effect of SARS-CoV-2 infection in human airway epithelial cells. Nat Commun. 2020 Aug 6;11(1): 3910.

75 Hou YJ, Okuda K, Edwards CE, Martinez DR, Asakura T, Dinnon KH 3rd, et al. SARS-CoV-2 reverse genetics reveals a variable infection gradient in the respiratory tract. Cell. $2020 \mathrm{Jul}$; 182(2):429-46.e14.
76 Stanifer ML, Kee C, Cortese M, Zumaran CM, Triana S, Mukenhirn M, et al. Critical role of type III interferon in controlling SARS-CoV-2 infection in human intestinal epithelial cells. Cell Rep. 2020 Jul;32(1):107863.

77 Katsura H, Sontake V, Tata A, Kobayashi Y, Edwards CE, Heaton BE, et al. Human lung stem cell-based alveolospheres provide insights into SARS-CoV-2-mediated interferon responses and pneumocyte dysfunction. Cell Stem Cell. 2020 Dec;27(6):890-e8.

78 Lamers MM, van der Vaart J, Knoops K, Riesebosch S, Breugem TI, Mykytyn AZ, et al. An organoid-derived bronchioalveolar model for SARS-CoV-2 infection of human alveolar type II-like cells. EMBO J. 2020 Dec;40(5):e105912.

79 Duan F, Guo L, Yang L, Han Y, Thakur A, Nilsson-Payant BE, et al. Modeling COVID-19 with human pluripotent stem cell-derived cells reveals synergistic effects of antiinflammatory macrophages with ACE2 inhibition against SARS-CoV-2. Res Sq. 2020 Aug: rs.3.rs-62758.

80 Salahudeen AA, Choi SS, Rustagi A, Zhu J, van Unen V, de la O SM, et al. Progenitor identification and SARS-CoV-2 infection in human distal lung organoids. Nature. 2020 Dec; 588(7839):670-5.

81 Lamers MM, Beumer J, van der Vaart J, Knoops K, Puschhof J, Breugem TI, et al. SARS-CoV-2 productively infects human gut enterocytes. Science. 2020 Jul;369(6499):50-4.

82 Zang R, Gomez Castro MF, McCune BT, Zeng Q, Rothlauf PW, Sonnek NM, et al. TMPRSS2 and TMPRSS4 promote SARS-CoV-2 infection of human small intestinal enterocytes. Sci Immunol. 2020 May;5(47):eabc3582.

83 Zhao B, Ni C, Gao R, Wang Y, Yang L, Wei J, et al. Recapitulation of SARS-CoV-2 infection and cholangiocyte damage with human liver ductal organoids. Protein Cell. 2020 Oct; 11(10):771-5.

84 Zhou J, Li C, Liu X, Chiu MC, Zhao X, Wang $\mathrm{D}$, et al. Infection of bat and human intestinal organoids by SARS-CoV-2. Nat Med. 2020 Jul; 26(7):1077-83

85 Krüger J, Groß R, Conzelmann C, Müller JA, Koepke L, Sparrer KMJ, et al. Drug inhibition of SARS-CoV-2 replication in human pluripotent stem cell-derived intestinal organoids. Cell Mol Gastroenterol Hepatol. 2020 Nov 10; 11(4):935-48.

86 Han Y, Duan X, Yang L, Nilsson-Payant BE, Wang P, Duan F, et al. Identification of SARSCoV-2 inhibitors using lung and colonic organoids. Nature. 2021 Jan;589(7891):270-5.

87 Monteil V, Kwon H, Prado P, Hagelkrüys A, Wimmer RA, Stahl $M$, et al. Inhibition of SARS-CoV-2 infections in engineered human tissues using clinical-grade soluble human ACE2. Cell. May 2020;181(4):905-e7.

88 Health, N. I. O. Recombinant Human Angiotensin-converting Enzyme 2 (rhACE2) as a treatment for patients with COVID-19 (APN01-COVID-19). 2020. Available from: https://clinicaltrials.gov/ct2/show/ NCT04335136. 